\title{
EFFORTS TO IMPROVE STUDENTS' MATHEMATICAL PROBLEM SOLVING ABILITY THROUGH CONTEXTUAL TEACHING AND LEARNING AT SMP NEGERI 1 BINJAI
}

\author{
${ }^{1}$ Desy Agustina Situngkir, ${ }^{2}$ E. Elvis Napitupulu \\ ${ }^{1}$ Fakultas Matematika dan Ilmu Pengetahuan Alam, Universitas Negeri Medan \\ ${ }^{2}$ Dosen Pendidikan Matematika, Universitas Negeri Medan \\ E-mail: desyagustina.situngkir@gmail.com
}

\begin{abstract}
The purpose of this research was to know whether contextual teaching and learning (CTL) approach could improve students' mathematical problem solving ability (SMPSA) in eighth grade of SMP Negeri 1 Binjai. The type of this research was Classroom Action Research. The subject of this research was students in class VIII-9 which consisted of 20 students. The object was SMPSA on cube and cuboid topic in eighth grade of SMP Negeri 1 Binjai Academic Year 2015/2016.This study consisted of two cycles. Each cycle had two meetings. SMPSA was tested in the end of cycle. Instrument used to collect data in this research were test and observation sheet. After giving a treatment to students, in the first cycle, the average score of their mathematical problem solving ability was 2.30. Ten of 20 students (50\%) obtained score $\geq 2.67$. The average score of teacher's activities in observation sheet was 2.66, which classified as good category. The average score of students' activities in observation sheet was 2.55 , which classified as good category. In the second cycle, the average score of mathematical problem solving ability was increased became 3.05 with 18 students $(90 \%)$ obtained score $\geq 2.67$. The average score of teacher's activities in observation sheet was 3.44, which classified as very good category. The average score of students' activities in observation sheet was 3.22, which classified as very good category. From the result of research, it can be concluded that the implementation of contextual teaching and learning (CTL) approach can improve students' problem solving ability. The suggestion that given for teachers is to be able to implement contextual teaching and learning (CTL) approach as an alternative in learning process that can improve problem solving ability.
\end{abstract}

Keywords : Contextual Learning, Mathematical Problem solving Ability

\section{INTRODUCTION}

Mathematics is one of the most important subjects that very close and can be found around us. When we walk away, many things that we look related to mathematics. Something that we look, can be formed into a problem. Then, from the problem we try to solve (called problem solving). As a framework, a problem as a developmentally appropriate challenge for which the participant has a goal but the means for achieving it is not immediately apparent (Polya, 2004; Schoenfeld, 1992). Problem solving requires making sense of the problem situation and the means necessary for making decisions, which direct an individual's understanding (Schoenfeld, 1992). To solve the problem is needed some starategies named problem solving. Mathematical problem solving is a process which involved the method solution is unknown in advance. To find the solution, students should map their

Desy Agustina Situngkir, E. Elvis Napitupulu. Efforts to Improve Students' Mathematical Problem Solving Ability Through Contextual Teaching and Learning at SMP Negeri 1 Binjai. Jurnal Inspiratif, Vol. 3, No. 3 Agustus 2017. 
knowledge about mathematics. There are four important phases to solve mathematics problem. In this research, problem solving ability according to Polya (2004) will be measured through students' ability to complete a problem by using problem solving steps as follows:

\section{Understanding the problem}

From this step, students should understand the problem that can be looked from being able to point out what the data, what the condition, and also what the problem showed.

\section{Devising a plan}

From this step, students make plan how to solve the problem, which solution that corresponds to the problem. Finding the connection between the data and the unknown.

3. Carring out the plan

From this step, students implement the plan of what they have planned before.

4. Looking back

Students able to derive the result diffrently and use method for some other problem.

\section{Problem Formulation}

In accordance with extent problem describe above, the research problem formulation in this study are:

1. How does contextual teaching and learning approach improve students' mathematical problem solving ability in learning and teaching cube and cuboid topic in eighth grade of SMP Negeri 1 Binjai?

2. How does learning management conducted by teacher in implementing contextual teaching and learning approach in learning and teaching cube and cuboid topic in eighth grade of SMP Negeri 1 Binjai?

3. How does learning activity of students by implementing contextual teaching and learning approach in learning and teaching cube and cuboid topic in eighth grade of SMP Negeri 1 Binjai?

\section{Research Objective}

Based on the problem formulation, then objectives of this research are as follows:

1. Improving students' mathematical problem solving ability through contextual teaching and learning approach in learning and teaching cube and cuboid topic in eighth grade of SMP Negeri 1 Binjai.

2. Knowing the learning management conducted by teacher in implementing contextual teaching and learning approach in learning and teaching cube and cuboid topic in eighth grade of SMP Negeri 1 Binjai.

3. Knowing the learning activity of students by implementing contextual teaching and learning approach in learning and teaching cube and cuboid topic in eighth grade of SMP Negeri 1 Binjai.

\section{RESEARCH METHODOLOGY}

\section{Type of Research}

The type of this research is classroom action research (CAR)

\section{Location and Time of Reseach}

The research was conducted in SMP Negeri 1 Binjai mathematics subject in even semester of academic year 2015/2016.

\section{Research Procedure}

According to Arikunto, et. al (2010), classroom action research consist of four stages, that is (1) planning, (2) action, (3) observation, and (4) reflection. Action Research Model are described in more detail in Figure 3.1 below:

Desy Agustina Situngkir, E. Elvis Napitupulu. Efforts to Improve Students' Mathematical Problem Solving Ability Through Contextual Teaching and Learning at SMP Negeri 1 Binjai. Jurnal Inspiratif, Vol. 3, No. 3 Agustus 2017. 


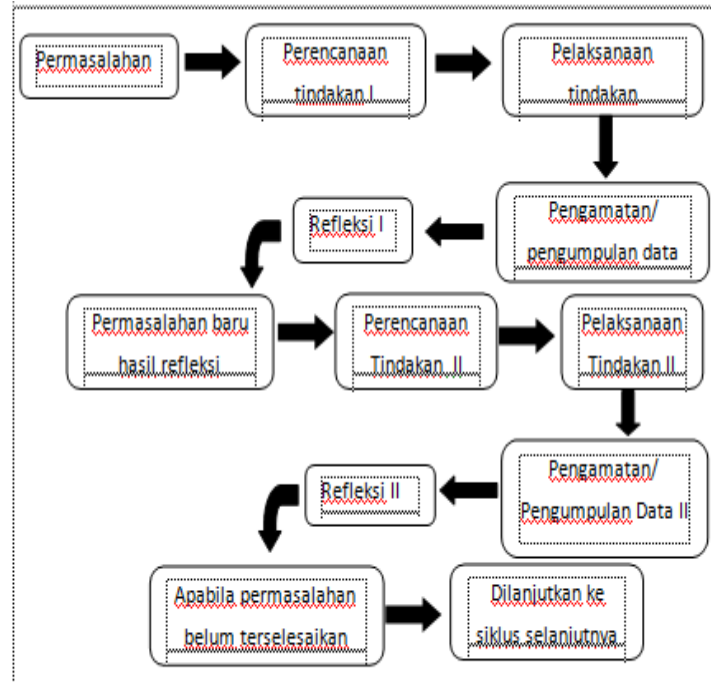

Figure 3.1, Chronology of Classroom Action Research (Arikunto, 2010)

\section{RESULT AND DISSCUSSION}

Based on previous observations that conducted by researcher in SMP Negeri 1 Binjai, found that students mathematical problem solving ability was low.

Subjects in this study were students of class VIII SMP Negeri 1 Binjai that consisted on 20 students. Before giving action, students were given initial test in form of problem solving, consisted of 1 question. This test was used to know the mathematical problem solving ability of students and to know difficulties that faced by students in mathematics subject.

Results of initial test were given at the beginning of the test could described level of student ability in solving problems. Of the 20 students, there is 1 student got predicate A-, 2 students got predicate D+, 17 students got predicate D. Complete result can be seen Table 4.1 and Figure 4.1:

\begin{tabular}{|c|c|c|c|c|c|c|}
\hline \multicolumn{7}{|c|}{ Table 4.l Initial Test Result } \\
\hline No & Score & Predicate & Criteria & $\begin{array}{c}\text { The } \\
\text { number of } \\
\text { Student }\end{array}$ & Percentage & $\begin{array}{l}\text { Average } \\
\text { of } \\
\text { students } \\
\text { ability }\end{array}$ \\
\hline 1 & $3.85-4,00$ & A & Very High & 0 & $0 \%$ & \multirow{11}{*}{0.96} \\
\hline 2 & $3.51-3.84$ & A- & High & 1 & $5 \%$ & \\
\hline 3 & $3.18-3.50$ & $\mathrm{~B}+$ & High & 0 & $0 \%$ & \\
\hline 4 & 2.85-3.17 & B & High & 0 & $0 \%$ & \\
\hline 5 & $2.51-2.84$ & B- & Moderate & 2 & $10 \%$ & \\
\hline 6 & $2.18-2.50$ & $\mathrm{C}+$ & Low & 0 & $0 \%$ & \\
\hline 7 & $1.85-2.17$ & $\mathrm{C}$ & Low & 0 & $0 \%$ & \\
\hline 8 & 1.51-1.84 & C. & Low & 0 & $0 \%$ & \\
\hline 9 & $1.18-1.50$ & $\mathrm{D}+$ & Very Low & 0 & $0 \%$ & \\
\hline 10 & $1.00-1.17$ & $\mathrm{D}$ & Very Low & 17 & $85 \%$ & \\
\hline \multicolumn{4}{|c|}{ Total } & 20 & $100 \%$ & \\
\hline
\end{tabular}

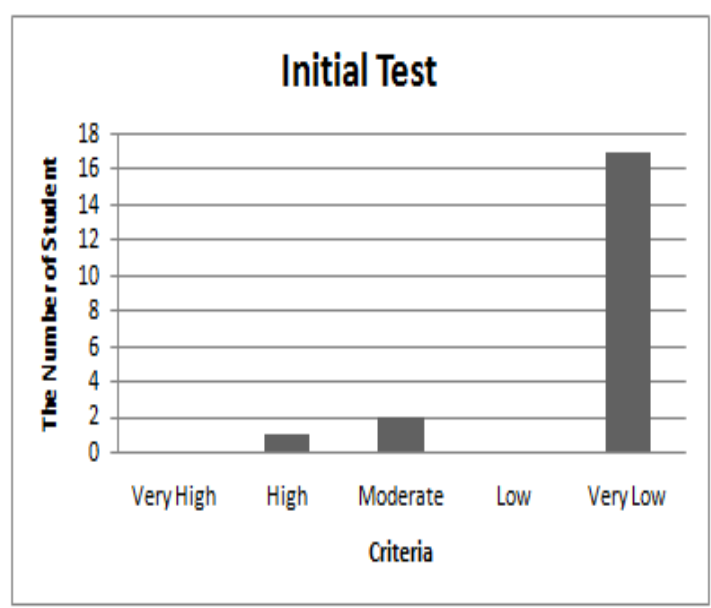

Figure 4.1 The Result of Initial Test

Based on data above, there are several obstacles that faced by students in solving problem, namely:

1. Students were not able to understand the problem, that was determining what known and what asked is of given problem.

2. Students were not able to relate between what known and what asked from problem.

3. In preparing plan of solving problem, students had not been able to implement the right strategies and procedures to solve problem.

4. Students were less scrupulous so they made mistakes in doing calculation.

Based on result of initial test can be concluded that students have not been able

Desy Agustina Situngkir, E. Elvis Napitupulu. Efforts to Improve Students' Mathematical Problem Solving Ability Through Contextual Teaching and Learning at SMP Negeri 1 Binjai. Jurnal Inspiratif, Vol. 3, No. 3 Agustus 2017. 
to solve mathematical problem solving. Realizing this condition, it was needed efforts to improve students' mathematical problem solving ability. Efforts that conducted to improve it, was by implementing Contextual Teaching and Learning.

In first meeting cycle I, teacher delivered the learning objective namely students reviewing about cube and cuboid and finding the concept of area. Teacher stimulated students to construct their knowleadge and inquiry the object related based on their experience. Further, teacher asked the students if they did not understand the material and then divided students become 5 groups that were arranged based on the result of initial test. A group consisted of 4 students. Then, teacher gave contextual problem related to the material in SAS 1. Teacher explained the task and responsibilityof each group disscusion that were followed in solving the problem containing in SAS 1. After doing activity in group, teacher gave oppotunity to a group to present the result in front of the class. In this phase, teacher acted as a facilitator during question and answer held. Futher, teacher reflected and concluded regarding the surface area of cube and cuboid. And the end of the first meeting, teacher gave assignment to be done individually.

At this first meeting, the mathematics teacher as an observer was asked to provide input by recording all the events that happened to researcher using observation sheet that has been provided. As the matters concerning observed were behavior of the teacher as a researcher during the learning process as well as the dynamics in the whole class learning activities using observation sheet. All record results will be analyzed and inputed used as a reflection to make improvements at the next meeting.

In the second meeting cycle I, teacher delievered the learning objectives to be achieved which students can calculated the surface area of cube and cuboid, then teacher stimulated the students to remind privious learning material.
Teacher gave SAS 2 and each group were resposible to discuss with their group. When the groups discuss with their groups, teacher looked around to manage the activity of students. Further, teacher called a group to present the result of their group. Teacher gave addition and conclusion about the surface area of cube and cuboid and provided tasks as homework individually. At the last meeting of cycle I, teacher gave problem solving ability test which done individually.

In general, the result of the test in problem solving ability test I can be seen in Table 4.2:

Table 4.2 Result of Problem Solving Ability Test I

\begin{tabular}{|c|c|c|c|c|c|c|}
\hline No. & Score & Predicate & Criteria & $\begin{array}{c}\text { The } \\
\text { number of } \\
\text { Student }\end{array}$ & Percentage & $\begin{array}{c}\text { Average } \\
\text { of } \\
\text { students } \\
\text { ability }\end{array}$ \\
\hline 1 & $3.85-4,00$ & $\bar{A}$ & Very High & 0 & $0 \%$ & \multirow{11}{*}{2.30} \\
\hline 2 & $3.51-3.84$ & A- & High & 0 & $0 \%$ & \\
\hline 3 & $3.18-3.50$ & $\mathrm{~B}+$ & High & 1 & $5 \%$ & \\
\hline 4 & $2.85-3.17$ & B & High & 3 & $15 \%$ & \\
\hline 5 & $2.51-2.84$ & B- & Moderate & 6 & $30 \%$ & \\
\hline 6 & $2.18-2.50$ & $\mathrm{C}+$ & Low & 2 & $10 \%$ & \\
\hline 7 & $1.85-2.17$ & $\mathrm{C}$ & Low & 2 & $10 \%$ & \\
\hline 8 & $1.51-1.84$ & C- & Low & 3 & $15 \%$ & \\
\hline 9 & $1.18-1.50$ & $\mathrm{D}+$ & Very Low & 3 & $15 \%$ & \\
\hline 10 & $1.00-1.17$ & D & Very Low & 0 & $0 \%$ & \\
\hline \multicolumn{4}{|c|}{ Total } & 20 & $100 \%$ & \\
\hline
\end{tabular}

The above data can be more clearly seen in Figure 4.3:

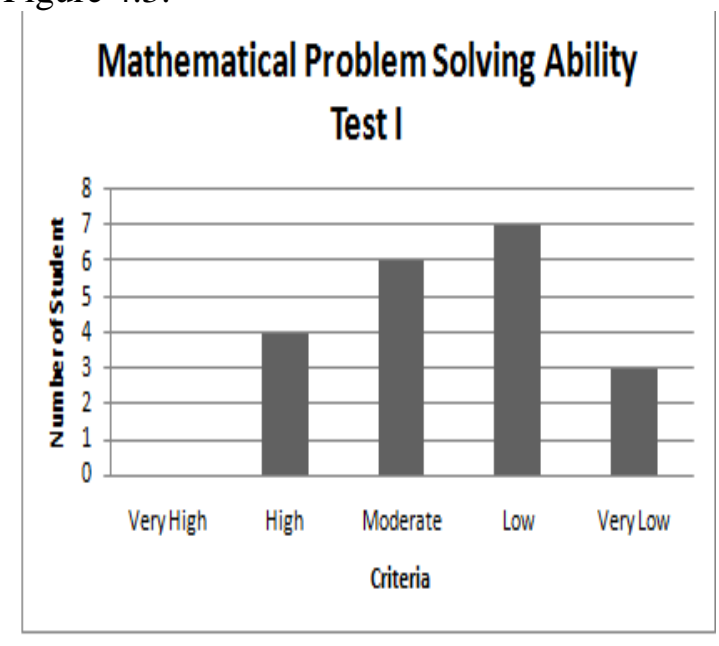

Figure 4.3 The Result of Problem Solving Ability Test I

Based on the test results of the first problem-solving abilities and observation data from observers find the results of the

Desy Agustina Situngkir, E. Elvis Napitupulu. Efforts to Improve Students' Mathematical Problem Solving Ability Through Contextual Teaching and Learning at SMP Negeri 1 Binjai. Jurnal Inspiratif, Vol. 3, No. 3 Agustus 2017. 
analysis of the difficulties experienced by students. First, problem solving ability test I showed some students have not been able to solve the problem using the problem solving steps and errors in solving the problem. Problem solving ability test I conducted at the end of the first cycle that 20 students, there were 4 students got high criteria, 6 students got moderate criteria, 7 students got low criteria and 3 students got very low criteria. Only 10 students who achieved score 2.66 or B- $(50 \%)$, while the level of mastery learning classically planned minimum of $85 \%$ of the number of students who take the test problem-solving abilities. Thus, learning in the first cycle was not yet success, because minimum mastery learning classically as one of indicator of success was not achieved.

Second, some students still face difficulty in finishing questions of problem solving. It can be seen from student that did not answer the question and student that made mistakes in solving the problem.

Third, the students in the group have not been fully able to work together and learn in a group with other words there were students who did not know clearly what the duties within the group. The success of the group in solving the problem on the student activity sheet was dominated by the ability of certain individuals who were in the group. This can be overcome by explaining the rules that apply in contextual teaching and learning. In contextual teaching and learning, each group member was responsible for understanding the problem, if there were members of the group who do not understand the problem then it will be a shared responsibility. So that, each group member was obligated to teach their friends in the group.

Fourth, the students as member of groups have not been entirely capable and courageous to present the results of group discussions. Based on observations of researchers in the first cycle only students who have more ability in the group that was able to present the work of the group, while for students who have a low ability tends to become a court reporter when conducting discussions and presentations. As a solution, the teacher as researcher motivated the whole group so that all members in the group were able to present the results of the discussion group in turn.

Fifth, the phases were applied during the learning process from the first meeting to the second meeting in the first cycle seem too forced to make the students to accomplish tasks also done in a hurry. Whereas in the implementation of contextual teaching and learning took much time, in this case the observer suggested to manage time efficiently in the third and fourth meeting. It was necessary to allow time for students to gather the information necessary to understand the concepts in solving problems.

Sixth, teacher already thought as well, can be seen in observation of teacher ability by observer. But, in the real learning process, students still have not adapted yet to contextual teaching and learning situation neither steps of problem solving. As a solution, teacher kept introducing and acquainting the students about interested contextual teaching and learning situation either how to solve the problem by using problem solving steps.

From data analysis above, researcher got the indicator of success have not been achieved yet, then researcher should continue to cycle II and repair process of teaching and learning so that indicator of success in cycle II can be achieved.

In cycle II, the problem derived from previous cycle that have not maximized and achived yet the target of research. Therefore, cycle II should be held so that target of this research could be achieved.

At the beginning of learning in first meeting cycle II teacher delivered the learning objectives that would be done that students could determine the volume of cube and cuboid. Further, teacher rearrange the students become 5 group based on the result of mathematical problem solving ability test I. Each group contained of 4 students, then teacher gave contextual problem related to material which was

Desy Agustina Situngkir, E. Elvis Napitupulu. Efforts to Improve Students' Mathematical Problem Solving Ability Through Contextual Teaching and Learning at SMP Negeri 1 Binjai. Jurnal Inspiratif, Vol. 3, No. 3 Agustus 2017. 
consisting in SAS. Teacher explained the tasks and responsibility for each group in the discussion activity to solve the given problem in SAS. At the further step, teacher distributed SAS 3 to each student and provided the clue to made students easier in solving the problems, during the discussion teacher going around to monitor the students' activities. In guiding activity, teacher gave more guidance to students in creating mathematical model and final solving strategy by giving question to awaken the students' knowledge. After finishing the problems in SAS to the specified time, teacher asked students to present their results of discussion.

When teacher asked the students to present or model their discussion results, students were very enthusiastic to move forward because each group had confidence and convinced that their discussion results were true and they mastered the problem if any group asked them. Students' enthusiasm to convey question and argument actually because the improving of students' activities to the better when they were discussing in the groups. At the end of learning, teacher together with students draw the conclusion of material just have been studied.

In the beginning of second meeting cycle II teacher delivered the learning objectives namely students could solve the problems related volume of cube and cuboid.

Before continuing the learning material, teacher gave the students chance to ask less understood material, then distributed SAS 4 then togather with each groups to discuss about the problems containing in SAS. During discussion in the group, teacher went around to monitor students' activities in each group. Teacher gave the helping to the group who found difficulty in solving the problem. When teacher went around monitoring students' activities, teacher did not find that students' were confused to understand problem and convert it to be mathematical model. All group can do SAS well.

For extending of students' understanding, teacher asked some groups to present the discussion result in front of class. Students were enthusiastic when asked to give question and perceive the presented answer by the presenter and draw the conclusion. Futher, teacher analyzed and reflected what has been learned from the experience of solving problem. After this second meeting then conducted mathematical problem solving ability test II to see the progress of students's mathematical problem solving ability during cycle II.

In general, the result of mathematical problem solving ability test II can be seen in Table 4.6 below :

\begin{tabular}{|c|c|c|c|c|c|c|}
\hline \multicolumn{7}{|c|}{ Table 4.6 Result Test of Problem Solving Ability II } \\
\hline No. & Score & Predicate & Criteria & $\begin{array}{c}\text { The } \\
\text { number of } \\
\text { Student }\end{array}$ & Percentage & $\begin{array}{c}\text { Average } \\
\text { of } \\
\text { students } \\
\text { ability }\end{array}$ \\
\hline 1 & $3.85-4,00$ & $\mathrm{~A}$ & Very High & 1 & $5 \%$ & \multirow{11}{*}{3.05} \\
\hline 2 & $3.51-3.84$ & A- & High & 1 & $5 \%$ & \\
\hline 3 & $3.18-3.50$ & $\mathrm{~B}+$ & High & 6 & $30 \%$ & \\
\hline 4 & $2.85-3.17$ & B & High & 6 & $30 \%$ & \\
\hline 5 & $2.51-2.84$ & B- & Moderate & 4 & $20 \%$ & \\
\hline 6 & $2.18-2.50$ & $\mathrm{C}+$ & Low & 1 & $5 \%$ & \\
\hline 7 & $1.85-2.17$ & $\mathrm{C}$ & Low & 1 & $5 \%$ & \\
\hline 8 & $1.51-1.84$ & C- & Low & 0 & $0 \%$ & \\
\hline 9 & $1.18-1.50$ & $\mathrm{D}+$ & Very Low & 0 & $0 \%$ & \\
\hline 10 & $1.00-1.17$ & D & Very Low & 0 & $0 \%$ & \\
\hline \multicolumn{4}{|c|}{ Total } & 20 & $100 \%$ & \\
\hline
\end{tabular}

The above data can be more clearly seen in Figure 4.10:

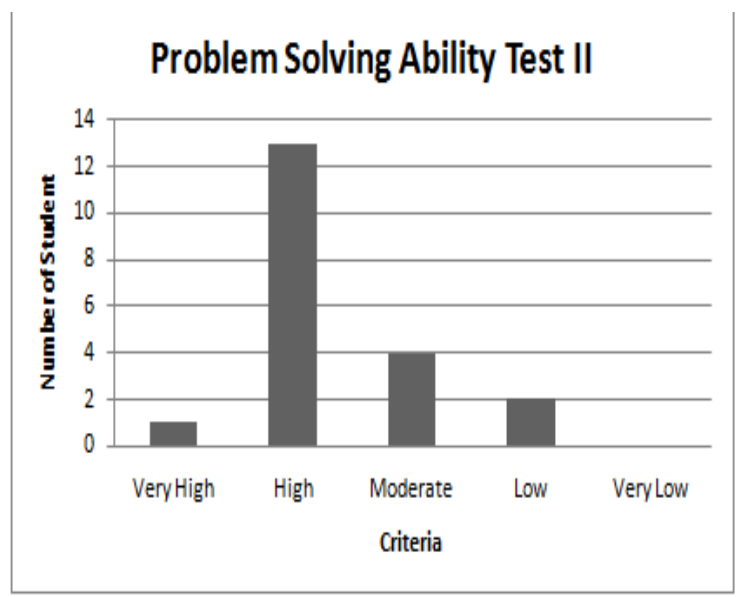

Figure 4.10 The Result of Problem Solving Ability Test II

After the evaluation of the second cycle given to the students and based on the observation of the data analysts, data and

Desy Agustina Situngkir, E. Elvis Napitupulu. Efforts to Improve Students' Mathematical Problem Solving Ability Through Contextual Teaching and Learning at SMP Negeri 1 Binjai. Jurnal Inspiratif, Vol. 3, No. 3 Agustus 2017. 
discussion of the obtained results the following conclusions:

First, the results of the second cycle of the evaluation showed that there was an increase in the results of the students' answers. The results of the evaluation of the second cycle in the form of problemsolving ability test II showed of 20 students, there were a student got $\mathrm{A}$ or included to very high criteria, 13 students got $\mathrm{A}-, \mathrm{B}+$ and $\mathrm{B}-$ or included to high criteria, 4 students got B- or included to moderate criteria, and 2 students got $\mathrm{C}+$ and $\mathrm{C}$ or included to low criteria. There were 18 students who achieved minimum score 2.67 or B-predicate. In other words, mastery learning classically reached $90 \%$, while planned level of mastery learning classical minimum was $85 \%$ of the number of students who take the test of problemsolving abilities. From the above data it can be concluded that the implementation of the second cycle of learning has been reached or meet the criteria of success indicator. In the second cycle, the problem solving ability of students has improved compared with the average of completeness of the cycle I. The gain normalization through cycle I to cycle II was 0.44 and interpreted in medium gain. The improvement showed that learning through contextual teaching and learning approach was successful in improving students' mathematical problem solving ability.

Second, the success of the second cycle by using contextual teaching and learning approach both in terms of teacher and students have shown very good results. In general, the average score of students's activity through cycle I to cycle II was 3.22 and categorized in very good. The average score of teacher's activities through cycle I to cycle II was 3.44 and categorized in very good. This means that learning management conducted by teacher and learning activity of students by implementing contextual teaching and learning approach is categorized very good and as the indicator of success, then teacher's activity and students' activity is achieved.
Third, even both teacher and students have shown very good result, there are 2 students still not achieve minimum score 2.67 or B-. This is happen because of limitted time so that not totally students could achieve minimum score 2.67 or B-. Many students have different ability in achieving materials, some students needed more time to catch the material.

From result of problem solving ability test I in cycle I and from result of problem based learning test II in cycle II above, it can be seen that students' ability in solving mathematical problems increased from previous test.

\section{CONCLUSION}

Based on the results of research and discussion can be concluded that:

1. Improving students' mathematical problem solving ability by implementing contextual teaching and learning approach in learning and teaching Cube and Cuboid topic in eighth grade of SMP Negeri 1 Binjai academic year $2015 / 2016$ was categorized in medium category.

2. Learning management conducted by teacher in implementing Contextual Teaching and Learning (CTL) approach in learning and teaching Cube and Cuboid topic in eighth grade of SMP Negeri 1 Binjai academic year $2015 / 2016$ is very good category.

3. Learning activities of students by implementing Contextual Teaching and Learning (CTL) approach in learning and teaching Cube and Cuboid topic in eighth grade of SMP Negeri 1 Binjai academic year $2015 / 2016$ is very good category.

Desy Agustina Situngkir, E. Elvis Napitupulu. Efforts to Improve Students' Mathematical Problem Solving Ability Through Contextual Teaching and Learning at SMP Negeri 1 Binjai. Jurnal Inspiratif, Vol. 3, No. 3 Agustus 2017. 


\section{REFERENCES}

Abdurrahman, M., (2009), Pendidikan Bagi Anak Kesulitan Belajar, Rineka Cipta, Jakarta.

Arikunto, S., (2012), Dasar - Dasar Evaluasi Pendidikan, Bumi Aksara, Jakarta.

Arikunto, S., (2010), Prosedur Penelitian Suatu Pendekatan Praktik , Rineka Cipta, Jakarta.

Asrori, M., (2007), Penelitian Tindakan Kelas, CV. Wacana Prima, Bandung.

Badan Standar Nasional Pendidikan, (2006), Standar Kompetensi dan Kompetensi Dasar Tingkat, Balitbang, Jakarta.

Berns, R., Erickson, P., (2001), Contextual Teaching and Learning: Preparing Students for The New Economy, The Highlight Zone Research @ work:

http://www.cord.org/uploadedfiles INCCTE_Highlight05-

ContextualTeachingLearning.pdf (accessed January-February 2016)

Center for student success, (2007), Contextualized Teaching \& Learning: A Faculity Primer, California Community Collage, California.

Crawford, M., (2001), Teaching Contextually, CCI Publishing Inc, Waco.

Goos, M., Galbraith, P., and Renshaw, P., (2000), A Money Problem: A Source of Insight Into Problem Solving Action, http://www.cimt. plymouth.ac.uk/journal/pgmoney.pd f (accessed January-February 2016)
Greattorex, J., (2013), Context in Mathematics Examination Question, Cambridge Assessment, Cambridge.

Hake, R., (1999). Analyzing Change/Gain Score, http://www.physics.indiana.edu/ sdi IAnalyzingChange-Gain.pdf (accessed January-February 2016)

Hudojo, H., (2005), Pengembangan Kurikulum dan Pembelajaran Matematika, UM Press, Malang.

Komalasari, K., (2010), Pembelajaran Kontekstual; Konsep dan Aplikasi, Refika Aditama, Bandung.

Lukito, A., Turmudi., Juandi, D., (2014), Matematika, Balitbang, Jakarta.

Math is Fun, (2014), https://www.mathsisfun.com/geomet ry/cuboids-rectangular-prisms.html (accessed January-February 2016)

Moyer, P.S., Niezgoda, D., and Stanley, J., (2005),Young Children's Use of Virtual Manipulatives and Other Forms of Mathematical Representations, In Masalaski, W.J., and Elliott, P.C., Technologysupported mathematics learning environments, National Council of Teachers of Mathematics:17-34.

National Council of Teacher of Mathematics, (2000), Principles and Standards for School Mathematics, NCTM, Reston Virginia.

Nurkencana, W., (1986), Menjadi Guru Profesional, Bumi Aksara, Jakarta.

Permendiknas No.22, (2006), Peraturan Mentri Pendidikan Nasional Republik Indonesia, Jakarta.

Permendiknas No.104, (2014), Peraturan Mentri Pendidikan Nasional Republik Indonesia, Jakarta.

Desy Agustina Situngkir, E. Elvis Napitupulu. Efforts to Improve Students' Mathematical Problem Solving Ability Through Contextual Teaching and Learning at SMP Negeri 1 Binjai. Jurnal Inspiratif, Vol. 3, No. 3 Agustus 2017. 
Polya, G., (2004), How to Solve It A New Aspect of Mathematical Method, Princeton Science Library, USA.

Ruseffendi, E., (2006), Pengantar Kepada Membantu Guru Mengembangkan Kompetensinya dalam Pengajaran Matematika untuk Meningkatkan CBSA, Tarsito, Bandung.

Rusman, (2012), Model-model Pembelajaran Mengembangkan Profesionalisme Guru Edisi Kedua, PT. Rajagrafindo Persada, Jakarta.

Sanjaya, W., (2005), Pembelajaran Dalam Implementasi Kurikulum Berbasis Kompetensi, Kencana Prenada Media Group, Jakarta.

Satriani, I., Emilia, E., and Gunawan, M., (2012), Contextual Teaching and Learning Approach to Teaching Writing, Journal of Applied Linguistics 2: 10-22.

Schoenfeld, A.H., (1985), Mathematical Problem Solving, Academic Press, New York.

Schoenfeld, A.H., (1992), Learning To Think Mathematically:Problem Solving, Metacognitif, And SenseMaking In Mathematics, MacMillan, New York.

Sukayati, (2008), Penelitian Tindakan Kelas, PPPPTK Matematika, Yogyakarta.

Suyanto, (1997), Pedoman Pelaksanaan Penelitian Tindakan Kelas (PTK) Pengenalan Penelitian Tindakan Kelas, Dirjen Dikti, Yogyakarta.

Trianto, (2009), Mendesain Model Pembelajaran Inovatif-Progresif, Prenada Media Group, Jakarta.

Wardhani, (2010), Pembelajaran Kemampuan Masalah Matematika di SMP, PPPPTK Matematika, Yogjakarta.

Wena, M., (2011), Strategi Pembelajaran Inovatif Kontemporer, Bumi Aksara, Jakarta.

Widjajanti, D.B., (2009), Kemampuan Pemecahan Masalah Matematis Mahasiswa Calon Guru Matematika: Apa dan Bagaimana Mengembangkannya, Seminar Nasional Matematika dan Pendidikan Matematika 25: 402413.

Yee, P.S., (2014), Developing A Contextualization of Students' Mathematical Problem Solving, Elsevier Inc, United Stated.

\section{${ }^{1}$ Desy Agustina Situngkir \\ ${ }^{2}$ E. Elvis Napitupulu}

